\title{
Factors Effecting Drug Relapse in Malaysia: An Empirical Evidence
}

\author{
Fauziah Ibrahim, $\mathrm{PhD}$ \\ Faculty of Social Sciences and Humanities \\ Universiti Kebangsaan Malaysia \\ E-mail: ifauziah@ukm.my \\ Naresh Kumar, $\mathrm{PhD}$ \\ Faculty of Economics and Management \\ Universiti Putra Malaysia \\ E-mail: naresh@putra.upm.edu.my
}

\begin{abstract}
It has been noted that many drug addicts relapse to drug use after discharged from successful treatment and rehabilitation programs. Thus it is imperative and timely to address the issues that prompt relapsed addiction. 400 drug addicts on relapse cases were selected from eight drug rehabilitation centres throughout Peninsular Malaysia to examine factors influences the relapsed addiction to drug use. Consistent with previous research, self-efficacy, family support, community support and employers support were identified as main factors that influenced the relapsed addictions tendency amongst addicts. Suggestions to curb relapsed addiction to drugs were discussed in relation to the findings.
\end{abstract}

Keywords: Relapse, Addiction, Drug, Malaysia

\section{Introduction}

The close geographical propinquity to Myanmar, Laos and Thailand (Golden Triangle) and other Southeast Asian countries that produces illicit drugs has intensify drug use in Malaysia. The illicit drug use been well thought-out as major social intimidation in Malaysia. The government, on February 19, 1983, declared drug as national disaster and endeavor with stringent law enforcement together with rehabilitation programs for addicts. Indeed the government through various agencies has put in action strategies to impede drug use, parallel to the mission of attaining a drug-free society by 2015 . Nevertheless, even with the country's stringent enforcement policy, there has been a sizeable ascends in the number of fresh and relapsed drug users (National Anti-Drug Agency (NADA), 2009). NADA entrusted by the Malaysian government to sculpt mechanisms to handle the drug crisis and in particular to trim down relapsed addiction rate.

Based on the statistics by NADA (2009), the number of detained drug addicts from January to December 2007 and 2008 were 14,489 and 12,352 respectively. Perhaps, the addiction trend that was recorded by NADA is some sort of a relief to all concern. In 2007, the detained fresh and relapsed addicts were 6,679 and 7,810 respectively. Among the detained drug addicts in 2008, 5,939 (48\%) were fresh addicts while 6,413 (52\%) were relapsed addicts. Interestingly, in 2008 the statistics revealed a decline of percentages in total number of detained addicts $(15 \%)$, new addicts $(11 \%)$ and relapsed addicts (18\%) compared to the reported statistics in 2007. Nevertheless, careful observation on the statistics revealed an increase in the number of detained relapsed addicts compared to new drug addicts between 2008 and 2007. Generally, it is well understood that the number of drug addicts should reduce dramatically upon successful completion of treatments or rehabilitation program. However, the reported data explicates that most of the drug addicts failed to sustain the free of drug lifestyle after they have been discharged from rehabilitation treatment program. Mohamad Hussain and Mustafa (2001) reported that there are evidence of $90 \%$ relapsed cases among heroin addicts within six months after been discharged from the Serenti rehabilitation centres. It also had been found that $40 \%$ of the addicts pine for heroin after a month of abstinence. Surprisingly, Serenti rehabilitation centers have relapsed inmates who have followed the rehabilitation sessions for more than five times. Moreover, Habil, (2001) contended that more than 70 percent of those attending drug rehabilitation centres would probably relapse. Reid, Kamarulzaman, and Sran (2007) alleged that though some of the programs had been successful, about 70 to 90 per cent of addicts who underwent rehabilitation probably 
return to the habit within first year after been discharged if they are compelled and detained at the rehabilitation centres. In any event, the rate of relapse among addicts is of great concern to both governmental and non-governmental bodies. Thus, this research was initiated to examine the factors contributing to relapsed addiction tendency amongst drug addicts in Malaysia. Indeed this study is significant and timely to fight against drug addictions to the root while achieving the nation's ambition to reach the zero drugs by 2015.

\section{Factors Contributing to Relapse among Drug Addicts}

Relapse is a formidable challenge in the treatment of all behavior disorders (Witkiewitz \& Marlatt, 2004). Several authors have described relapse as complex, dynamic and unpredictable (Buhringer, 2000; Donovan, 1996; Marlatt, 1996). Whereas according to Mahmood (1996), relapsed addiction means, usage, intake or misuse of psychoactive substances after one had received drug addiction treatment and rehabilitation, physically and psychologically. To Rasmussen (2000), relapse occurred because of the building up of additional crisis such as to look trivially on certain problem, stress, weak or failed forecast, the pessimistic thinking that all issue cannot be resolved and immature actions. Relapsed addicts also confused and overreact due to the inability to think clearly, unable to manage feelings and emotions, the difficulty to remember things, unable to control their feelings and easily angered.

Various studies have examined the effects of psychosocial factors towards relapse among drug and alcohol dependence. Moos (2007) contended that psychological factors are supposition to contribute to relapse among drug addicts after abstinence. Consistently, anxiety has been linked to increased relapse risk among marijuana addicts (Arendt et al., 2007; White et al., 2004). Other relapse promoting factor is self-efficacy, defined as a degree to which an individual feels confident and capable performing a certain behavior in a specific situational context (Bandura, 1977). As described in the cognitive-behavioral model of relapse (Marlatt, Bear \& Quigley, 1995), high levels of self-efficacy are predictive of improved alcoholism treatment outcomes (Brown et al., 1995; Greenfield et. al., 2000; Rychtarik, Prue, Rapp \& King, 1992). The situation is different from the results of research done on 60 alcoholics, which found that individuals who have high self-efficacy after going through rehabilitation treatment, are most unlikely to be addicted again (Allsop, Saunders \& Phillips, 2000). Chuah (1990), in his research found that drug addicts who have low self-efficacy would be back to addiction after their release from getting treatment and rehabilitation. Other previous studies have also point out that improvement in self-esteem positively lead to success in rehabilitation programs and it assist in curbing drug addictions (Graham et al., 1997; Mahmood, 1995; Mahmood et al.,1998; Mahmood et al., 1999).

Attitude and poor knowledge on drug abuse been reported to be contributing factor of relapsed addictions among drug addicts (Abdullah \& Iran, 1997). Besides, less support from family members and the community by large towards former addicts highly promote the relapsed addiction tendency after treatment (Brown et al., 1995; Miller et al.,1999; Miller, 1992; Moos \& King, 1997). Research by Mohd Taib, Rusli and Mohd Khairi (2000) on family communication patterns amongst addicts' family and non addicts' family, showed weak communication patterns and less effective interactions amongst former addicts' family is one of the high probable factors toward drug addiction. Indeed, family support is much needed to ensure the rehabilitation process success and issues like "don't care attitude" and ostracizing former addicts would only failed the rehabilitation process and in the long run caused the former addicts to relapse (Daley \& Marlatt, 1992).

Amongst other factors that have been associated with relapsed addiction are peer pressures especially from the old friends who still use drugs. Mahmood, et al. (1999) found 50\% of old friends influenced former addicts to pick up the drug taking habit after they were discharged from rehabilitation centres. The research also showed that $76 \%$ of the old friends assist rehabilitated individuals to get the needed supply of drugs. These situations further induced the relapsed addiction amongst former addicts who has been getting rehabilitation treatments. However, the above research is different from findings by Chuah (1990). He found peers support could help former addicts from not getting back to the old habit. He concluded that high emotional and spiritual support will indirectly increase the addicts' self confidence and decrease the risk towards relapsed addiction. Gregoire and Snively (2001) reported that addicts who have discharged from rehabilitation centres and living in drug-free social environments could be linked with higher abstinence rates and low in relapse of drug use.

Mc Coy and Lai (1997), on the other hand, associates inability to get jobs amongst former addicts who were discharged from rehabilitation centres coupled with lack of financial supports, caused the addicts to go back to addictions. Yunos (1995) asserted that employers always took advantage on the former addicts by paying low salaries without taking into consideration their qualifications and experience, causing dissatisfactions amongst the former addicts that eventually caused them to quit their jobs.

Yahya \& Mahmood, (2002), found that the treatment and rehabilitation programs being conducted in any country would faced various challenges. The effectiveness of drug rehabilitation programs also one of the factors, associated with relapsed addictions amongst addicts. This is because some researchers found drug rehabilitation programs conducted on addicts are less effective to jolt them to awake (Mokhtar, 1997, Wellish \& Prondergast, 1995). Many research found that the traditional treatment and rehabilitation models failed to help in reducing relapse addiction to drug use (Habil, 2001; 
Mahmud Mazlan, Schottenfeld \& Chawarski, 2006; Mohamad \& Mustafa, 2001; Mahmood, Md Shuaib Che Din and Ismail Ishak, 1998; McLellan, 2002; Nestler, 2002; O'Brien, 2006 ; Reid, 2007).

Though, sufficient rehabilitation programs are in place, prevention of relapse to drug will pass its best if physiology and psychology strength of addicts faint in due time. In addition, lack of multiple long term treatment modalities, social intervention and additional pharmacological treatment could abet relapse. Hence, relapse to drug use after extended periods of abstinence remains as most intricate clinical problem and research issue in the treatment of drug addiction (Miller et al., 1999; O'Brien, 2006; Sinha \& Li, 2007). Individuals involved in recovery and the treatment of recovering individuals recognize that sustaining a clean and sober life is perhaps significantly more difficult than eliminating the use of the drug. There is a high degree of consensus in the field that relapse is a common element in the recovery process. Nevertheless, examination of factors which contributes to relapse is indispensable to develop successful interventions in curbing future relapse to drug-taking behavior (Donovan, 1996; O'Brien, 2006, Sinha \& Li, 2007). The present study intended to identify the extent that self-efficacy; support from peers, family, employers, community; and programme effectiveness at drug rehabilitation centres influences the relapsed addiction amongst drug addicts. The findings of this research is advantageous to the government, namely the Home Ministry, NADA, social workers, drug counselors, psychologist and other human services in particular, Malaysia and other regions in general.

\section{Method}

The primary data was obtained through a survey using self-administered questionnaire. Items from established instruments were adopted and modified appropriately to suit the objectives of the study. The instrument consists of five parts. The first part of the questionnaire collected the demographic information of the respondents. Second part consist 42 items developed by Marlatt and Gordon, (1985) to measure the tendencies of relapsed addiction among the addicts. The items specifically measures three dimensions; negative emotion, interpersonal conflict and social pressure. Part 3, 4 and 5 obtained information pertaining to self-efficacy, sosial-environment factors (support form peer, family, employer, and community) and rehabilitation programme effectiveness respectively. Self-efficacy was measured using 15 items developed by Sherer and Maddux (1982) while 5 items from Abdullah and Iran (1991) was employed to measure attitude towards drug abuse. 30 items developed by Procidano and Heller (1983) used to measure peer and family support. 12 items created by the researchers to measure employer and community support. The program effectiveness at drug rehabilitation centres was measured using 26 items developed by Bahaman, et al. (2003). The respondents were asked to respond on a scale ranging from strongly disagree (1) to strongly agree (4). From the analysis, it was identified that the Cronbach alpha of all constructs exceeds Nunnally's (1978) recommended threshold value of 0.7. Thus, the instrument used in this study showed a good level in terms of reliability. The respondents were chosen by systematic sampling procedure. 400 questionnaires were personally distributed to the relapsed addicts who are undergoing treatments and rehabilitations in eight Narcotics Rehabilitation Centres in Peninsular Malaysia. Counselors from the respective centres help to disseminate and collect the survey. High response rate (100\%) for this study is due to high degree of cooperation by the respondents and the centres' counselors. In addition, the drop and pick method utilized in this survey was very effective. The data were analyzed using SPSS Version 15.

\section{Findings and Discussion}

\subsection{Respondents' background}

Majority of the respondents (86\%) involved in this research were aged 30 years and above. $80 \%$ of them were Malays and Muslims and in terms of marital status, $65 \%$ were single. From the data on educational level, $91 \%$ of the respondents were holding Sijil Pelajaran Malaysia (Malaysian Certificate of Education, equivalent to O'levels). About $47 \%$ of them used to work as temporary workers.

\subsection{Factors promoted relapsed addiction amongst drug addicts in Malaysia.}

Respondents perceptions on all factors contributing to relapsed addiction were categorized as low, moderate and high based on the possible score range. Table 1 shows the summary of the findings. About 97 percent of the respondents indicated moderate to high level of agreement on attitude towards drug abuse. 68 percent of the respondents agreed to moderate level of self-efficacy. In short, the findings showed that respondents received moderate to high level of support from peers (99 percent) and family (96 percent) in their endeavor towards free from drug use. On the other hand respondents reported that they received low to moderate level of support from employers ( 98 percent) and community ( 94 percent) on the whole. About 99 percent of the respondents indicated moderate to high level of satisfactory with the rehabilitation programme at the respective centres.

Table 2 displays the Pearson's correlation coefficients between the research variables which indicate the strength of relationship between the seven factors with respect to perceived tendency of relapsed addiction to drug use. Out of seven factors identified to promoting relapsed addiction, only four factors showed significant correlation at the 0.05 level. The factor with the highest correlation to tendency of relapsed addiction to drug use is self-efficacy $(r=-.790, p<.05)$. Community support $(r=-.315, p<.05)$, was found to be moderately correlated with relapsed addiction to drug use. Factors 
with low degree of correlation with relapsed addiction to drug use were family support $(r=-.207, p<.05)$ and employer support $(r=-.193, p<.05)$. The negative associations between the variables indicate that high (low) self-efficacy; community support, family support, and employer support lead to a reduced (increase) number of relapsed addiction to drug use.

Self-efficacy is the factor identified as the main contributor towards relapsed addiction tendency amongst the addicts in Malaysia. The findings of this research found most former addicts showed low self-efficacy that eventually drove them back to addiction and became relapsed addicts. In this research, among the character identified that led to the low self confidence amongst relapsed addicts, according to the 400 questionnaires distributed were as follows: $58 \%$ agreed that they did not have strong personal strength and would stop doing something before they can solve it; $54 \%$ said they would not start something if they would face difficulties; $53 \%$ admitted that they easily quit if they could not finish something; $55 \%$ agreed with the statement that they always shirk from trying something new; $75 \%$ said that they would easily surrender and 58\% admitted that they does not have the will to solve problems in their lives. The findings of this research also showed that about $7 \%$ of the former addicts who has the confidence to do something as planned.

Based on the situation mentioned earlier, it is no surprised why former addicts in Malaysia are easily to be trapped once more in the relapsed addiction situation and this factor is identified as the major contributor towards relapsed addictions tendency amongst the addicts. In reality this research found most former addicts has no strong self confidence to overcome problems, easily giving up and did not solve any problem in positive and prudent way. Because of these, they were easily influenced by factors which would drive them towards relapsed addiction especially after they were released from drug treatment and rehabilitation. The findings is seen as parallel with findings from research by Chuah (1990) which found addicts with low self-efficacy issue, are more likely to become addicts for second time after they were released from drug treatment and rehabilitation.

Community support is the second factor that contributes towards relapsed addiction tendency amongst addicts. The responds showed most respondents agreed with the following reasons that drove them back to relapsed addiction: $64 \%$ felt that they were not received well by the community; $77 \%$ felt that the community always look sideways on them and $66 \%$ felt that they were always being the suspects whenever there is robbery or theft incidence in their area. On the other hand, this research found that only $22 \%$ received strong support from the community like neighbors and village heads who helped them to be away completely from drugs. Indeed, as member of a community, each individual plays certain roles to help the fight against drugs, regardless their status in the community. Without cooperation from the community, the government's desire to rehabilitate former addicts and to turn them into useful citizen would not be achieved because of the society's prejudicial attitude that does not want to accept wholly, the repented addicts.

According to the random research conducted by Mahmood (1996) on 60 family units in the northern Peninsular, showed $95 \%$ respondents from the community gave the impression that they thought the addicts are a group of people who has no use to the nation. Only $18 \%$ amongst them thought that drug addiction is a sickness that needs to be treated and $6 \%$ thought that all addicts should be removed to another place far away from the community and would not be allowed to come back because of their mistakes and should not be forgiven.

These short findings showed that the community in Malaysia still find difficult to accept drug addicts for the mistakes they have done. At the present time community support, in totality, is crucial to help shedding the negative opinion on former drug addicts. The community should change their thinking, be more liberal and accept the former addicts back as a new member who comes back into their fold. The community should also play active role in fighting against drug trafficking and misuse within their community, by cooperating with the authorities. Apart from that the community should be ready to guide the former addicts so they would not trapped again in the drug addiction, through various intervention programs, arranged by drug prevention agencies and non-govenmental organizations.

Family support is the third main factor identified contributing to the relapsed addiction tendency. The findings showed that lack of open interaction between former addicts with the family members increases relapsed addiction tendency amongst the addicts. 57\% of the respondents admitted that they would feel uneasy and find difficult to express their problems with family members. This situation, if left prolonged, would be able to stress the former addicts and lead to many difficult situations for one and others. According to Mohd Taib and Mohd Khairi, (2000), among the causes that create the uneasiness amongst addicts to confront the family with their problem is caused by lack of communication and ineffective interaction amongst members of the family. This weak family communication pattern would cause the drug misuse amongst the children.

In this research $59 \%$ respondents agreed to say that their family members who are facing with problems would come up to them to get advises. While $60 \%$ respondents agreed to say that their family members would come up to them to get emotional and spiritual support. This situation gave impression that not only the former addicts need support from their family to be free from drugs, but their family members also relaying on them whenever they faced with problems. This dependency more or less pressured the former addicts because they have to shoulder the family's problems and in the end, caused them to lose control and to seek easy way out by turning to addictions. Because of that, family should be 
responsible in playing their important role in helping former addicts to lead a life that is free of drugs. This is because, according to the past researches, problematic families showed positive relationship with drug usage (Brook, Whiteman \& Gordon, 2002)

The findings of this study revealed that $98 \%$ of the respondents perceived that they received low to moderate level of support from their employees. This situation shows that majority of employers are still skeptical with the attitude of former drug addicts which directly influence them to narrow down or close the employment opportunities to ex-addicts. More specifically, $79 \%$ of the respondents supposed that their former employers not in favor to employ them after released from rehabilitation centres. On the other hand $74 \%$ of the respondents alleged that their employers will terminate their employment if they were found to be ex-drug addicts. This finding is parallel to the evidence reported in the literature (Mahmood, 2006; Mc Coy \& Lai, 1997; Yunos, 1996).

\section{Implications for Practice}

To raise the self confidence level, the addicts, former addicts, drug counselors, social workers, family members and the members of community should work hand in hand and play their roles effectively and efficiently in uplifting the spirits and to revive self confidence in the former addicts so they can build new meaningful life. The former addicts have to be trained on how to have strong determination as well as strong internal resilience to stay away from drugs. The high spirits and self confidence would determine their faith and help them to face difficulties after they re-enter the community. Brownell, Marlatt, Lichtenstein and Wilson, (1980) and Miller (1985) confirmed that former addicts had showed strong commitment and motivation to stay away and to preserves the free from drug status quo.

Drug counselors in Malaysia are advised to strengthen and to stress on principle aspect of self-help to the former addicts in the rehabilitation modules, so that they can build high defensive spirits and wants the improvements in their lives while getting the treatments and rehabilitations. The identity building is one method or strategy towards individual and community building for long term and continuously. With identity, it would help them to be independent in order to take care and to manage their lives, better.

As for the family, employers and community, they should be ready to work hand in hand to take over the role played by drug counselors after the addicts are released. According to Patricia \& Robert (2005), an addicts who received treatment in rehabilitation centre, usually has determination and self confidence that they could be able to stay away from drug addiction once more. They have strong spirits to rehabilitate while they are freed. However, after they finished with the treatment process and released, their situation were the other way around. This is because they found out that the environment out of the rehabilitation centres does not support them as they hoped. Because of that, all members of community should be more sincere in helping and guiding former addicts by giving them undivided support and encouragement to former addicts so they can be more self-assured to continue with their lives. With the cooperation of all party, is should help the former addicts to build their lives that should be more self assured and highly confidence to continue to lead their lives, healthy and free from drugs.

\section{Conclusion}

This study concludes that the main cause of relapsed addictions amongst drug addicts in Malaysia grounded by the addicts who are lack of strong self-efficacy to avoid temptations, hurdles and challenges in life. They are extremely sensitive individuals, easily emotional and easily stressed by social pressures from the environment. The impact of the weak personality and self-efficacy caused them their good judgments in managing their life, which should be safer and free from drugs. Although they thought that the drug rehabilitation programs they have gone through in two years is effective to help rehabilitate them from the drug effects and received strong support from friends and family to be able to free from drug, these factors would not be able to stop them from continuously chained by drug problems after they were released. This is because they continued to be tagged as 'no good' individuals or the 'community's trash' by the community after they were released from rehabilitation centres, causing them to feel uneasy to mingle with the community, to be more ostracized, low self esteem, and felt them being left out. The situation would becoming worst and pressured when efforts to get jobs amongst the former addicts met the dead end. This is because most employers are prejudicial and has no confidence in their ability to contribute in the productivity of the nation. With low self-efficacy and the feeling of being ostracized by the community and employers raised conflict and psychological imbalance in the addicts. These confusions are the factors that drove former addicts to the old habits by taking up drugs, after their new life faced the difficulties and challenges.

\section{Limitations and Future Research}

The present study has several limitations which could be good avenues for future research. This research focused on selected rehabilitation centres located in Peninsula Malaysia. To understand inclusive contributing factors for drug relapse, representation from treatment and rehabilitation centres from Sabah and Sarawak are well encouraged. Moreover the issue pertaining to generalizability of the findings beyond Malaysia could be reasonably brought into compromise. 
Present study is a cross sectional study which may limit the depth of findings and discussion. Longitudinal studies are vital to address the issues of cause and effect more precisely pertaining to relapsed cases. Future researchers are encouraged to replicate this study and explore more dynamic factors which contribute to relapsed addiction to drugs using qualitative research approach.

The present study focused solely on relapsed drug addicts and ignored the new addicts who were attending the treatment and rehabilitation programs. Future research should compare and contrast factors contributing for drug relapse base on the responses of relapsed and new drug addicts enrolled in rehabilitation centres nationwide. Such comparisons will help in generating strategic plans to narrow down the drug dilemmas.

This study does not look in the possibility of individual characteristics to serve as moderating or intervening variables to relapsed addiction to drug use. It would be worthwhile to incorporate individual characteristics to see at what extent these characteristics jointly influence attitude towards relapse to drug use.

\section{References}

Abdullah Al Hadi \& Iran Herman. (1997). Penagihan Dadah Mengikut Kaum: Diri, Keluarga dan Persekitaran. Kuala Lumpur: Perpustakaan Negara Malaysia.

Aendt, M., Rosenberg, R., Foldager, L., Perto, G., \& Munk-Jorgensen, P. (2007). Psychopathology among cannabis-dependent treatment seekers and association with later substance abuse treatment. Journal of Substance Abuse Treatment, 32, 113-119.

Allsop, S., Saunders, B., \& Philips, M. (2000). The Process of Relapse in Severely Dependent Male Problem Drinkers. Journal of Addiction, 95, 95-106.

Bahaman Abu Samah, Rahim Sail, Sidek Mohd Noad, Jamilah, Tuan Suria Idris, Kamsiah Kamin, \& Tuan Kamarul Alam Taib. (2003). The Influence of Rehabilitation Programmes, Self Concept, Peers and Family in Addressing Recidivism. Serdang: Universiti Putra Malaysia.

Bandura, A. (1977). Self Efficacy: Toward a Unifying Theory of Behavior Change. Psychology Review, 84(2): 191-215.

Brook, J.S., Whiteman \& Gordon. (2002). Longitudinally Foretelling Drug Use in the Late Twenties: Adolescent Personaliti and Sosial Environmental Antecedent. Journal of Genetic Psychology, 161(1), 36-42.

Brown, S.A., Vik, P.W., Patterson, T.L., Grant, I., \& Schuckit, M.A. (1995). Stress, vulnerability and adult alcohol relapse. Journal of Studies on Alcohol, 56, 538-545.

Brownell, K.D., Marlatt, G.A., Linchtenstein, E., \& Wilson, G.T. (1980). Understanding and Preventing Relapse. American Psychologist, 41:765-782.

Buhringer, G. (2000). Testing CBT mechanisms of action: Humans behave in a more complex way than our treatment studies would predict. Addiction Journal, 95, 1715-1716.

Chuah Mooi Kim. (1990). Keyakinan Diri Penagih Dadah: Hubungannya Dengan Sokongan Sosial dan Faktor Demografi. Latihan Ilmiah. Bangi: Universiti Kebangsaan Malaysia.

Daley, D.C. (1987). Relapse Prevention with Substance Abusers: Clinical Issues and Myths. Sosial Work, 45(2), 38-42.

Donovan, D.M. (1996). Marlatt's classification of relapse precipitants: Is the Emperor still wearing clothes? Addiction Journal, 91, 131-137.

Graham, W. \& Wexler, H. (1997). The Amity therapeutic communities program: Description and approach. In DeLeon, G. (Ed). Community as a method: Modified therapeutic communities for special populations and special settings. Springfield: Greenwood Press.

Greenfield, S., Hufford, M., Vagge, L., Muenz, L., Costello, M., \& Weiss, R. (2000). The relationship of self-efficacy expectancies to relapse among alcohol dependent men and women: A prospective study. Journal of Studies on Alcohol, 61, $345-351$

Gregoire, T. K., \& Snively, C. A. (2001). The relationship of social support and economic self-sufficiency to substance abuse outcomes in a longterm recovery program for women. Journal of Drug Education, 31(3), 221-237.

Habil, H. (2001). Managing heroin addicts through medical therapy. Kuala Lumpur: University Malaya Press.

Mahmood Nazar Mohamed (1996). Peranan \& Penglibatan Keluarga dan Masyarakat Dalam Pencegahan Penagihan Berulang. Jurnal PERKAMA. Bil.6.ISSN 0127/6301. Persatuan Kaunseling Malaysia.

Mahmood Nazar Mohamed, Mohd Shuib Che Din, Lasimon Matokrem, Muhamad Dzahir Kasa \& Rusli Ahmad. (1999). Penagihan Dadah dan Residivisme: Aspek-Aspek Psikososial dan Persekitaran. Kedah: Pusat Penyelidikan dan Perundingan, Universiti Utara Malaysia. 
Mahmood, N.M. \& Mohd Yunos Pathi Mohd (2002). Program evaluation of PENGASIH House, Malaysia: Some reflections on the differences in the self-esteem and personality. Paper presented at the $5^{\text {th }}$ Asian Federation of Therapeutic Communities Conference, 18-23 August, Bangkok, Thailand.

Mahmood, N.M., Ismail Ishak \& Azniza Ishak. (2002). Self-esteem and self acceptance amongst rehabilitated heroin users: A 12-months post treatment study in Malaysia. Paper presented at the Hawaii International Conference on Social Science, June 11-15, Honolulu, Hawaii.

Mahmood, N.M., Md Shuaib Che Din \& Ismail Ishak. (1998). Treatment of drug dependents in traditional settings. Pakistan Journal of Psychological Research, 13 (3/4), 75-87.

Mahmud Mazlan, Schottenfeld, R.S. \& Chawarski,M.C. (2006). New Challenges and Opportunities in Managing Substance Abuse in Malaysia. Drug and Alcohol Review, 25(5), 473-478.

Marlatt, G.A. \& Gordon, J.R. (1985). Relapse Prevention: Maintenance Strategies in the Treatment of Addictive Behaviors. New York: Guilford Press.

Marlatt. G. A. (1996). Lest taxonomy become taxidermy: A comment on the relapse replication and extension project. Addiction Journal, 91, 147-153.

Mc Coy. C. B \& Lai. S. (1997). No Pain, No Gain, Establishing the Kunming, China, Drug Rehabilitation Center. Journal of Drug Issues. 27 (1):73-85.

Miller, M.W. (1985). Motivation for Treatment: A Review with Special Emphasis on Alcoholsm. Psychological Bulletin, 98:84-107.

Miller, M.W. (1992). The Effectiveness of Treatment for Substance Abuse: Reasons for Optimism. Journal of Substance Abuse, 9, 93-102.

Miller,N.S., Ninonuevo, F., Hoffmann, N.G., \& Astrachan, B.M. (1999). Prediction of treatment outcomes: lifetime depression versus the continuum of care. American Journal on Addictions, 8, 243-253.

Mohamad Hussin Habil \& Mustafa Ali Mohd. (2001). Managing drug addiction: mission is possible. Ampang: Penerbitan Salafi.

Mohd Taib \& Mohd Khairi. (2000). Pola-pola Komunikasi Kekeluargaan: Kajian di kalangan Keluarga Penagih dan Bukan Penagih di Negeri Kedah. Penyelidikan Sekolah Pembangunan Sosial.

Mokhtar Mohamad. (1997). Faktor-Faktor Kegagalan Membebaskan Diri Daripada Dadah. Unpublished Master's Thesis: Universiti Putra Malaysia.

Moos, R. (2007). Theory-based processes that promote remission of substance use disorders. Clinical Psychology Review, 27, 537-551.

Moos, R. H., \& King, M. J. (1997). Participation in community residential treatment and substance abuse patients' outcomes at discharge. Journal of Substance Abuse Treatment, 14(1), 71-80.

National Anti-Drug Agency (NADA). (2009). Ministry of Home Affairs, Malaysia. [Online] Available: www.adk.gov.my. (February 20, 2009).

Nestler, E. J. (2002). From neurobiology to treatment: progress against addiction. Nat Neurosci, 5 Suppl, 1076-1079.

Nunnally, J. (1978). Psychometric theory, (2 nd ed.). New York: McGraw-Hill.

O’Brien, C. (2006). Drug addiction and drug abuse. In L. L. Brunton, J. S. Lazo, \& K. L. Parker (Ed.), Goodman and Gilman's The Pharmacological Basis of Therapeutics (11th ed., pp. 607-627). New York: McGraw-Hill.

Patricia, S. \& Robert, L.S. (2005). Substance Abuse Counseling: Theory and Practice (3rd Edition). New Jersey: Pearson Merill Prentice Hall.

Procidano, M.E. \& Heller, K. (1983). Measures of Perceived Social Support From Friend and From Family in Drug Abuse Prevention: Three Studies. American Journal of Community Psychology, 11, 1-24.

Rasmussen, S. (2000). Addiction Treatment: Theory and Practice. Beverly Hills, California: Sage Publication, Inc.

Reid, G., Kamarulzaman, A. \& Sran, S.K. (2007). Malaysia and harm reduction: The Challenges and Responses. International Journal of Drug Policy, 18(2), 136-140.

Rychtarik, R. G., Prue, D. M., Rapp, S., \& King, A. (1992). Self-efficacy, aftercare and relapse in treatment program for alcoholics. Journal of Studies on Alcohol, 53, 435-440.

Sherer, M \& Maddux, J.E. (1982). The Self-Efficacy Scale Contraction and Validation. Psychology Reports, 51, 663-671

Sinha, R. \& Li, C.S. (2007). Imaging stress- and cue-induced drug and alcohol craving: association with relapse and clinical implications. Drug and Alcohol Review. 26, 25-31. 
Wellish, J. \& Prendergast, M.L. (1995). Towards a Drug Abuse Treatment System. Journal of Drug Issues, 25(24): 759-782.

White, A. M., Jordan, J. D., Schroeder, K. M., Acheson, S. K., Georgi, B. D., Sauls, G., et al. (2004). Predictors of relapse during treatment and treatment completion among marijuana-dependent adolescents in an intensive outpatient substance abuse program. Substance Abuse, 25, 53-59.

Witkiewitz, K. \& Marlatt, G.A. (2004). Relapse Prevention for Alcohol and Drug Problems. American Psychologist, 59, 224-235.

Yahya Don \& Mahmood Nazar Mohamed. (2002). Penagihan Dadah \& Perlakuan Jenayah: Pengaruh Faktor Psikososial dan Institusi. Jurnal psikologi Malaysia. Julai 2002. Bil.16: ISSN 0127-8029.

Yunos Pathi Mohamed. (1996). Dilema, Pengalaman dan Prospek Bekas Penagih Dadah. Kertas Kerja Seminar Dari Institusi Pemulihan Ke Pangkuan Masyarakat, Anjuran Yayasan Pencegahan Jenayah Malaysia. Hotel Crown Princess, Ogos 1996.

Table 1. Perception on factors promoting to relapsed addiction $(n=400)$

\begin{tabular}{lc|c|cc|c}
\hline & \multicolumn{3}{c|}{ Level of Perception } & \\
\cline { 2 - 4 } \multicolumn{1}{c}{ Variables } & $\begin{array}{c}\text { Low } \\
\mathrm{n}(\%)\end{array}$ & $\begin{array}{c}\text { Moderate } \\
\mathrm{n}(\%)\end{array}$ & $\begin{array}{c}\text { High } \\
\mathrm{n}(\%)\end{array}$ & Mean & SD \\
\hline self-efficacy & $71(17.8)$ & $274(68.4)$ & $55(13.8)$ & 1.96 & 0.56 \\
Attitude towards drug abuse & $11(2.8)$ & $145(36.2)$ & $244(61.0)$ & 2.58 & 0.55 \\
Peer support & & & & & \\
Family support & $6(1.5)$ & $307(76.7)$ & $87(21.8)$ & 2.20 & 0.44 \\
Employer support & $15(3.8)$ & $300(75.0)$ & $85(21.2)$ & 2.17 & 0.47 \\
Community support & $170(42.5)$ & $222(55.4)$ & $8(2.0)$ & 1.59 & 0.53 \\
Rehabilitation programme & $166(41.5)$ & $211(52.7)$ & $23(5.8)$ & 1.64 & 0.59 \\
effectiveness & $6(1.5)$ & $218(54.5)$ & $176(44.0)$ & 2.43 & .52 \\
& & & & & \\
\hline
\end{tabular}

Note: Low ( $\leq 2.00)$; Moderate (2.01-3.00); High (3.01-4.00)

Table 2. Pearson's correlation between factors promotes addiction and tendency of relapse to drug use

\begin{tabular}{lcc}
\hline Variables & $\mathbf{r}$ & $\boldsymbol{p}$ \\
\hline self-efficacy & -.790 & $.000^{*}$ \\
Attitude towards drug abuse & -.010 & .841 \\
Peer support & -.052 & .302 \\
Family support & -.207 & $.000^{*}$ \\
Employer support & -.193 & $.000^{*}$ \\
Community support & -.315 & $.000^{*}$ \\
Rehabilitation programme effectiveness & -.049 & .325 \\
\hline
\end{tabular}

Note: *Correlation is significant at the 0.01 level $(2$-tailed $)$ 